\title{
CONCEPTUALIZATION OF GEOGRAPHICAL SPACE IN THE SCIENTIFIC LITERATURE
}

\author{
Serhiy PUHACH \\ Lesya Ukrainka Eastern European National University, Lutsk, Ukraine \\ puhachserhiy@gmail.com
}

\begin{abstract}
Space is one of the fundamental concepts of human consciousness. Many sciences use the concept of space to describe their own subject areas. For geography, this concept is basic. By analogy with other sciences, geography has formed its own understanding of space - geographical space. In different historical epochs, people have differently represented space. Today, the most widespread are substantive and relational approaches to the interpretation of space. According to the substantive approach, space is a substance, independent of time and matter that acts next to and independently of them. According to the relational approach, space is understood as systems of relations that are formed between objects in the process of their interaction. Among Ukrainian geographers, E. Marunyak, K. Nemets, Y. Oliynyk, A. Stepanenko, O. Smyrnov, O. Topchiyev, O. Shabliy and others elaborated on the concept of geospace and geospatiality. Geographic space is a set of objects that are ordered on the earth's surface, together with the sum of all their connections and interrelations. It is not just the total sum of the geographical positions of all geographical objects, but a new quality that appears as a result of the general interactions of the objects on the earth's surface. In interpretations of geographical space, the following common features can be distinguished: geospace is one of the aspects of ordering geographical objects; geospace is a collection of relationships between objects; geographical space is characterized by both discreteness and continuity. Meanwhile, in Western scientific literature the concept of geographical space has not become noticeably widespread. Researchers often use the terms "space" and "social space". Geospace in Englishlanguage scientific literature is understood as the outer space near the Earth, including the upper atmosphere, the ionosphere, and the magnetosphere.
\end{abstract}

Key words: space, geographical space (geospace), continuity, discreteness, substantive approach, relational approach.

DOI: https://doi.org/10.17721/2413-7154/2019.82.27-33

UDC: 911.3

Received: November 24, 2019.

Revised: December 23, 2019.

Accepted: December 24, 2019.

\section{КОНЦЕПТУАЛІЗАЦІЯ ПОНЯТТЯ ГЕОГРАФІЧНИЙ ПРОСТІР У НАУКОВІЙ ЛІТЕРАТУРІ}

\section{Сергій ПУГАЧ}

Східноєвропейський начіональний університет імені Лесі Українки, м. Луцьк, Україна puhachserhiy@gmail.com

\begin{abstract}
Анотація: Простір є одним із фундаментальних понять людської свідомості. Багато наук використовують поняття «простір» для опису власних предметних областей. Для географії це поняття є базовим. По аналогії з іншими науками, географія сформувала власне розуміння простору - географічного простору. У різні історичні епохи людина по різному уявляла простір. Сьогодні найбільш поширені субстанціональний та реляційний підходи до трактування простору. За субстанціональним підходом простір - це самостійна по відношенню до часу та матерії субстанція, яка діє поруч і незалежно від них. За реляційним підходом простір розуміють не як самостійну суть, а як системи відносин, що утворюються між матеріальними об'єктами у процесі взаємодії. Серед українських географів теоретичним проблемам осмислення геопростору належать праці Є. Маруняк, К. Нємця, Я. Олійника, А. Степаненка, О. Смирнова, О. Топчієва, О. Шаблія та ін. Географічний простір - це сукупність впорядкованих відносно земної поверхні об'єктів, разом із усією сумою всіх їх зв'язків. Це не просто загальна сума географічних положень усіх географічних об'єктів, це нова якість, яка виникає внаслідок загальної взаємодії об'єктів на земній поверхні. У трактуваннях географічного простору можна виділити наступні спільні риси: геопростір - це один із аспектів упорядкування географічних об'єктів; геопростір - це сукупність зв'язків між об'єктами; для географічного простору характерна одночасно і дискретність, і континуальність. Тим часом, у західній науковій думці концепція географічного простору не набула помітного поширення. Дослідники найчастіше вживають терміни «space» та «social space». Під геопростором (geospace) у англомовній науковій літературі розуміють «область космічного простору біля Землі. Сюди входять верхні шари атмосфери, іоносфера, а також магнітосфера.
\end{abstract}

Ключові слова: простір, географічний простір (геопростір), континуальність, дискретність, субстанціональний підхід, реляційний підхід. 


\section{Вступ}

Сучасна система наук, яка $\epsilon$ основою сучасної людської цивілізації оперує тисячами різноманітних понять та термінів. Одні 3 них $€$ вузькоспеціалізованими та використовуються лише у окремих наукових напрямках, інші - представлені ширше та входять до понятійно-термінологічного апарату великої кількості наук. Одним із таких понять є поняття «простору». Простір є одночасно i простим, і складним терміном. Усвідомлення простору $\epsilon$ одним із вроджених властивостей людини. Через осягнення простору людина пізнає навколишній світ. Кожен 3 нас розуміє, що таке простір, проте, коли попросити дати йому визначення, описати його властивості, у людини починаються труднощі.

\section{Теоретико-методологічні основи дослідження}

Спробам осягнути сутність простору пронизана уся історія наукової думки, у т. ч. географічної, від Стародавньої Греції (Демокріт, Епікур, Лукрецій) до сьогодення. Серед українських географів теоретичним проблемам осмислення простору (геопростору) належать праці С. Маруняк, К. Нємця, Я. Олійника, А. Степаненка, О. Смирнова, О. Топчієва, О. Шаблія та ін. Проте, не зважаючи на багаточисленні спроби, відсутнє єдине уніфіковане трактування поняття.

\section{Мета і завдання дослідження}

Головною метою дослідження є систематизація наукових трактувань понять «простір» та «географічний простір», визначення їх властивостей та характерних рис у вітчизняній та зарубіжній науковій літературі. Головним завданням - на основі узагальнення дати власне трактування поняття «геопростір».

\section{Виклад основного матеріалу}

Переважна більшість суспільних, природничих, гуманітарних, технічних наук використовують поняття «простір» у своїй термінології для опису власних предметних областей. Для географії, поруч із фізикою та геометрією, це поняття є базовим. Для глибшого «географічного» розуміння простору, спочатку нам необхідно дати його визначення у філософських студіях де це поняття сформувалося й поширилося на інші наукові дисципліни.

Поняття простору є одним із фундаментальних понять людської свідомості. Воно є надзвичайно складним та має велику кількість різноманітних визначень. У різні епохи свого розвитку людина по різному уявляла та трактувала простір.

У первісному суспільстві простір в усвідомленні людей був вмістилищем реальних об'єктів і

\footnotetext{
(C) Serhiy Puhach
}

міфічних образів. Давньогрецькі філософи (Демокріт, Епікур, Лукрецій) розглядали простір як однорідну, нескінчену, нерухому порожнечу, заповнену атомами. Вплив цієї концепції прослідковується і у наш час при спробах дати найпростіше визначення простору. Протилежну концепцію простору відстоював Арістотель, який заперечував існування порожнини. Тому його простір заповнений місцями, які займають різні тіла. Ці дві концепції, фактично, започаткували субстанційний і реляційний підходи до сприйняття i розуміння простору, які розвивалися впродовж багатьох століть [13, с. 16].

У релігійних і об'єктивно-ідеалістичних концепціях простір і час трактувались як утворені разом 3 матерією Богом або абсолютним духом. 3 точки зору теології до Бога поняття простору i часу неприйнятні, оскільки він існує за межами простору i часу у вічності. У суб'єктивноідеалістичних концепціях висувались еклектичні i внутрішньо суперечливі тлумачення простору i часу як апріорних форм чуттєвого споглядання (I. Кант) або як форм упорядкування комплексів відчуттів і дослідних даних, встановлення між ними функціональних залежностей (Дж. Берклі, Е. Мах, позитивізм) [16, с. 439-440].

Розвиток науки у XX ст. розкрив нові аспекти простору і часу. Спеціальна теорія відносності (1905) показала залежність та нерозривний зв'язок простору і часу від руху матеріальних об'єктів. Загальна теорія відносності (1916) підтвердила, що простір і час - не самостійні сутності, а форми існування матерії. Зокрема, виходячи з цієї теорії, відносними треба визнати, лінійні розміри, час i одночасність подій.

Поява загальної теорії відносності призвело до створення у XX ст. нової наукової картини світу та формування поняття чотиривимірного континуального простору-часу, у якому три однорідні просторові координати доповнюються координатою часу і тому всі явища розглядаються у динаміці - як процеси. Виникло абстрактне поняття математичного простору 3 безкінечною вимірністю, яке стало дієвим інструментом аналізу і опису складних багатовимірних об'єктів, до яких відносяться i суспільно-географічні об'єкти [14, с. 17].

Сьогодні найбільшого поширення набули два основні підходи до трактування простору: субстанціональний, реляційний.

За субстаниіональним підходом (Демокріт, I. Ньютон) простір розуміється як самостійна по відношенню до часу та матерії сутність (субстанція), яка діє поруч і незалежно від них. Звідси висновок, про незалежність властивостей простору від об'єктів та процесів, які відбуваються у ньому.

За реляиійним підходом простір розуміють не як самостійну суть, а як системи відносин, що утворюються між матеріальними об'єктами, які взаємодіють. Поза такою системою взаємодій простір і час вважають неіснуючими. Реляційна концепція допускає 
залежність властивостей простору i часу від характеру взаємодії речей, властивостей i відносин [6, с. 269].

У науковій літературі $[2 ; 4 ; 6 ; 8 ; 9 ; 16]$ простір наділяється наступними властивостями та ознаками:

- об’єктивність і незалежність від свідомості людини;

- нерозривний зв’язок простору та часу між собою;

- простір виступає як загальна властивість (атрибут) об'єктів (матеріï);

- не існує об'єктів поза простором;

- не існує простору поза предметами (матерією). Звідси наслідок: простір завжди чимось заповнений;

- кількісна і якісна нескінченність;

- структурність, тобто здатність поділятися на окремі частини;

- протяжність, тобто зміни характеру зв'язків i взаємодій складових елементів, їх чисельності, взаємного розташування, якісних особливостей;

- гетероструктурність - існування у просторі різних об'єктів (точкових, лінійних, площинних, об'ємних), полів;

- ізотропність - рівноправність усіх можливих напрямів руху;

- неперервність (континуальність) - відсутність «розривів» у просторі;

- зв'язність - наявність взаємодії між елементами простору;

- тривимірність (іноді додається четвертий вимір «час») - фундаментальна властивість, яка емпірично констатується. Виражається у тому, що положення будь-якого об'єкта можна визначити за допомогою трьох незалежних величин: довжини, висоти, ширини;

- однорідність простору - відсутність якихось виділених точок чи ділянок.

Що ж таке простір? Яку дефініцію йому можна дати? У ряді енциклопедичних видань ми зустрічаємо різноманітні трактування поняття «простір». Ось декілька 3 них.

Простір - це форма буття матерії, яка характеризує їі протяжність, структурність, співіснування і взаємодію елементів в усіх матеріальних систе$\max [6$, c. $267 ; 9$, с. $540 ; 16$, с. 440$]$.

Простір - філософська категорія, за допомогою якої позначається форма буття речей та явищ, яка відображає їх співбуття та співіснування [8].

Простір - поняття, яке характеризує взаємне розташування співіснуючих об'єктів [4, с. 468].

Простір - те, що залишиться, якщо забрати все; порожнеча, але порожнеча в трьох вимірах [2].

Простір (математ.) - множина об'єктів, між якими встановлені відношення, подібні за своєю структурою зі звичайними просторовими відношеннями типу оточення, відстані та ін.

Отже, у сучасні науковій літературі відсутне єдине розгорнуте трактування поняття «простору», а багаточисельні визначення мають дискусійний характер.
Простір може трактуватися у різних аспектах. Особливо яскраво проявляється узагальнююча, об'єднувальна властивість цього поняття. Вона виходить 3 тощо, що у розумінні сучасної науки простір не може бути порожнім - він обов'язково чимось наповнений. Тому всі об'єкти, що знаходяться у просторі, розглядаються як об'єднані просторово, тобто належать одному просторові. Такий підхід дозволив розширити поняття простору на сукупність однорідних подій, явищ, процесів тощо. Вживання поняття простору у такому аспекті взагалі не є строгим і грунтується на його інтуїтивно зрозумілій об’єднувальній здатності [14, с. 14-15].

Так з'явилися поняття «соціальний простір», «географічний простір», «економічний простір», «освітній простір», «простір подій», «етнічний простір», «національний простір», «релігійний простір», «цивілізаційний простір», «водний простір», «повітряний простір», «регіональний простір», «локальний простір», «людський простір», «архітектурний простір», «театральний простір», «художній простір», «віртуальний простір», «геополітичний простір», «життєвий простір», «правовий простір», «сенсомоторний простір», «перцепційний простір», «поведінковий простір», «простір потоків», «протір очікування» та ін.

Ряд наук вивчають специфічні форми вияву простору у мікросвіті, живій природі, соціальній сфері. Спеціально досліджуються соціальний, геологічний, історичний, художній та інші види часу і простору [2, с. 271]. Так, В. Вернадський у своїх працях неодноразово використовував поняття біологічного простору.

Характерною особливістю більшості наук, що оперують різними «просторами», $є$ те, що вони хоча й вживають це поняття, але спеціально не обгрунтовують його в теоретичному та методологічному аспектах. Географія, на відміну від них, не може лишатися осторонь від теоретикометодологічних баталій, оскільки простір для неї $€$ предметом дослідження, інструментом пізнання, ключовим пояснювальним принципом. Ситуація ускладнюється тим, що для географії принципово необхідно зв'язати природничо-наукове та соціокультурне розуміння простору, тоді як інші науки (літературознавство, фізика) цим можуть й знехтувати [10, с. 17].

Простір, без сумніву, є одним із найважливіших понять системи географічних наук. Без простору неможливо уявити географію, як науку. Про географічність терміну «простір» свідчить те, що в англійській мові слово «space» (простір) вживається також як синонім слова відстань. В англомовній географічній літературі, на відміну від нашої, набагато частіше вживаються терміни «простір/просторовий» (space/spatial) ніж «територія/територіальний (territory/territorial) чи «географія/географічний» (geography/geographic(al)). Просторовий (хорологічний) підхід багато науковців вважає ядром географії, одним iз головних інтегруючих елементів системи географічних наук $\lceil 10 ; 14\rceil$. Існує навіть думка про 
географію, як «просторознавство» [10].

Розуміння простору людським суспільством багато в чому визначало напрямки розвитку географії як наукової дисципліни. По аналогії 3 іншими науками, географія сформувала власне розуміння простору - географічного простору.

Перші уявлення про концепцію географічного простору виникли у працях К. Ріттера та А. Геттнера. Низка вчених-географів намагалася дати визначення даного поняття. Слабкість деяких сучасних трактувань географічного простору полягає насамперед у простому механічному перенесенні фізичного або ейнштейнівського просторучасу в географію. Багато науковців взагалі не виділяють простір, як одну з головних категорій географії. Це виявляється насамперед у вживанні термінів «простір» та «територія» у якості синонімів. У географії за допомогою поняття простір часто намагаються поєднати (сумістити) різнорідні речі, обгрунтовуючи тим самим цілісність світу [10, с. 16].

Е. Б. Алаєв (1983) вважав, що оскільки поняття простору формується не у рамках географії, то географічна наука може лише інтерпретувати це загальнонаукове поняття відносно до специфіки власного предмету дослідження. В цьому значенні географічний простір, у найзагальнішому вигляді, повинен трактуватися як філософська концептуальна категорія, як об'єктивна, загальна та пізнавана форма існування матеріальних географічних утворень та об'єктів в межах геоверсуму [1, с. 98]. Географічний простір (геопростір) за Е. Б. Алаєвим - сукупність відношень між геооб'єктами, які розміщені на конкретній території (геоторії) та розвиваються у часі [1, с. 100].

Специфікою географічного простору є те, що він може формуватися якими завгодно об'єктами, явищами та відношеннями (якщо вони географічні), але обов'язковою умовою повинна бути наявність серед цих об'єктів геоторії (території). Географічний простір одночасно має якості перервності (географічний об'єкт займає власне положення у фізичному просторі) та неперервності (географічний об'єкт має власне географічне поле). Власний фізичний простір об'єкта разом із його географічним полем утворюють географічний простір об'єкта. Філософська концепція єдності простору та часу вимагає включення у визначення географічного простору ознаки динамічності $[1$, с. 99]. Основними властивостями географічного простору є: структурність, системність, динамічність, розмірність, дискретність, континуальність, ентропія [1, с. 101-103].

Концепція геопростору за Е. Б. Алаєвим у географічні науці виконує переважно методологічні функції. Для географа географічний простір завжди пов'язаний із територією. Образно кажучи, географічний простір - це не «скриня без стінок» (як у філософів) а «скриня» у якої обов'язково є одна «стінка» - поверхня Землі [1, с. 104].

На думку О. I. Шаблія географічний простір $\epsilon$ проблемою, яку досліджують на метанауковому рівні, тобто це не предметна область географії, а методологічна та логічна. Географічний простір - це абстрактний об'єкт науки, що не піддається безпосередньому спостереженню; конструктивний об'єкт науки (конструкт); підпростір системи земних просторів [18, с. 66].

Континуум простір-час яскраво проявляється лише у випадку високих швидкостей та великих мас, які не прослідковуються під час взаємодії природи та суспільства. Тому вивчаючи земний простір можна розумово абстрагуватися від часової компоненти, що в жодному разі не применшує значення часових аспектів географічного дослідження.

Властивостями гепростору, за О. Шаблієм, $€$ структурність, бар'єрність, неоднорідність, інверсійність (“стягування" простору у певних напрямках), ергодизм (фіксація процесів та подій минулих часів), метричність [18, с. 76-77].

К. А. Нємець вважає, що поняття географічного простору у більшості аспектів не відрізняється від поняття тривимірного фізичного простору: однозначне визначення місцеположення об'єктів, їх просторових взаємовідносин, відстаней, площ, об'ємів, кутових та лінійних характеристик руху та ін. Принциповою відмінністю географічного простору $\epsilon$ наявність відношень та зв'язків об'єктів і явищ. У ньому розглядаються не тільки географічні об'єкти, а й поля властивостей об'єктів. У такому розумінні географічний простір має подвійну природу. 3 одного боку, географічні об'єкти є дискретними утвореннями з конкретними лінійними розмірами. 3 іншого - поля параметрів географічних об'єктів континуальні i для їх опису географічний простір має розглядатися як неперервний. Звідси географічний простір - сукупність місць географічних об'єктів та відношень і взаємодії між ними [14].

Є. О.Маруняк доповнює визначення геоопростору Е. Алаєва часовою складовою. Так, геопростір - це сукупність відношень та взаємозв'язків між географічними об'єктами, що розташовані на конкретнійтериторії та розвиваються у часі під впливом природних та антропогенних чинників [12, с. 40].

О. Г. Топчієв $(2005,2009)$ розуміє географічний nростір (геопростір) - як одне з фундаментальних понять суспільної географії, яким позначають впорядкованість географічних об'єктів відносно земної поверхні та їх просторову організацію. Географічний простір - це множина географічних об'єктів, які мають свої місцеположення, та множина відношень i взаємодій між ними [23, с. 167]. Географічний простір має метричні (кількісні аспекти, в першу чергу протяжність) та топологічні (неперервність, зв'язаність, тривимірність, впорядкованість та ін.) властивості [22, c. 130].

За М. Д. Шаригіним географічний простір - це сполучення геосистем та сукупність відношень координації та протяжності співіснуючих різнорідних елементів. Тісний взаємозв'язок просторового аспекту з часовим дозволяє говорити 
про просторово-часову структуру, як субстрат географічних подій. Звідси, правильно говорити не про географічний простір, а про географічний простір-час [19].

Формалізований аспект географічного простору найбільш чітко проявляється на картах, ступінь вияву його структурних відмінностей можна оцінити за допомогою методу районування [15, с. 54]. Основними властивостями геопростору за Я. Олійником та А. Степаненком є регіоналізм, взаємодія складових елементів, континуальність, дискретність, структурність, внутрішня суперечність, інтегративність.

Я. Олійник та А. Степаненко вживають поняття сочіально-географічного простору - це частина географічного простору, що являє собою просторовочасове поєднання суспільних об'єктів, явищ i процесів у сукупності із природним оточенням; це простір суспільства із усіма сферами географічного середовища; це простір антропосфери (заселеної, освоєної, або в інший спосіб втягненої в орбіту життя суспільства частини географічної оболонки землі з їі просторовими структурами господарства $\mathrm{i}$ формами організації життя суспільства) [15, с. 56].

Є. Маруняк пропонує розглядати соціальноекономічний простір як частину геопростору, утворену сукупністю об'єктів та суб'єктів господарювання, соціальних груп населення, інституційних структур і взаємовідношеннями між ними, а також потоками речовини та енергії, сформованими в процесі взаємодії 3 природним середовищем [12, с. 40].

У західній науковій думці концепція географічного простору не набула помітного поширення. $\mathrm{y}$ енциклопедичних виданнях із суспільної географії [7; 24; 25] термін «географічний простір» відсутній. Дослідники найчастіше вживають терміни «space» та «social space». Під геопростором (geospace) у англомовній науковій літературі розуміють «область космічного простору біля Землі. Сюди входять верхні шари атмосфери, іоносфера, а також магнітосфера. Його можна назвати областю взаємодій системи Сонце-Земля» [3].

Термін «географічний простір» (geographical space) зустрічається порівняно рідко $[11$, с. $287 ; 17$; 20 , с. 1610] i трактується як «специфічний географічний термін для позначення організованих людиною місць у яких відбувається взаємодія між соціальними групами та навколишнім середовищем» [5]. Звертає увагу те, що словосполучення «географічний простір» використовується у працях науковців, для яких англійська мова не є рідною $[11 ; 17]$, тобто для англо-американської географії цей термін не є характерним.

\section{Висновки}

Отже, поняття простру є одним із базових у сучасній системі наук, яке стоїть на одному рівні 3 такими категоріями, як час, матерія, форма, взаємодія, рух, розвиток, взаємовплив та ін. Спроби філософами дати йому однозначне трактування поки що успіхів не дали. Багато наук оперує дефініцією простору. Не є винятком і географія, для якої це поняття є ключовим. У системі географічних наук сформувалася концепція географічного простору (геопростору).

У вітчизняних трактуваннях «географічного простору» можна виділити наступні спільні риси:

1) геопростір - це один із аспектів упорядкування (розміщення) географічних об’єктів;

2) геопростір - це сукупність відношень (зв’язків) між об'єктами на певній території;

3) географічні об’єкти у геопросторі є одночасно і дискретними, і континуальними;

4) географічний простір є одним із ключових понять метагеографії, науки, яка перебуває на етапі становлення. Саме тому його обгрунтуванню у сучасній географії приділяється відносно мало уваги.

Отже, на нашу думку, географічний простір - це сукупність впорядкованих відносно земної поверхні об'єктів, разом із усією сумою всіх їх відношень (зв’язків). Це не просто загальна сума географічних положень усіх географічних об'єктів (від найменшого до найбільшого), це нова якість, яка виникає внаслідок загальної взаємодії об'єктів на земній поверхні.

$\mathrm{У}$ наш час коли йде інтенсивний наступ на географію зі сторони інших наук, географам варто було б активніше розробляти концепцію геопростору, особливо у іiі взаємозв'язках та взаємодії 3 віртуальними просторами, такими як кіберпростір, простір соціальних он-лайн мереж та ін.

\section{References:}

1. Alaev Je. B. Social'no-èkonomičeskâ̂ geografiâ: ponâtijno-terminologičeskij slovar' [Socio-economic geography: a conceptual and terminological dictionary]. Moscow: Mysl', 1983, 350 p. (In Russian).

2. Comte-Sponville A. Filosofskij slovar' [Philosophical Dictionary]. Moscow: OOO Izdatel'stvo Èterna, 2012, 752 p. (In Russian).

3. Definition of 'Geospace'. In: The Economic Times. URL: https://economictimes.indiatimes.com/definition/ geospace. [20 December 2019].

4. Frolov I. T. (ed.). Filosofskij slovar' [Philosophical Dictionary]. Moscow: Respublika, 2001,719 p. (In Russian).

5. Geographical space. In: Euston96. Online encyclopedia. URL: https://www.euston96.com/en/geographicalspace/ [20 December 2019]. 
6. Gorlač M. İ., Kremen' V. G., Nikolaênko S. M., Trebìn M. P. etc. Osnovi fillosofs'kih znan'. Fìlosofiâ, logìka, etika, estetika, religiêznavstvo [Fundamentals of philosophical knowledge. Philosophy, Logic, Ethics, Aesthetics, Religious Studies]. Kyiv: Centr učbovoï literaturi, 2008, 1028 p. (In Ukrainian).

7. Gregory D., Johnston R., Pratt G., Watts M. J., Whatmore S. (eds.). The Dictionary of Human Geography. 5th Edition. Chichester: Wiley Blackwell, 2009, 1071 p.

8. Gritsanov A. A. (ed.). Novejšij filosofskij slovar' [The latest philosophical dictionary]. Minsk: Knizhnyj Dom, 2003, 1280 p. (In Russian).

9. Il'ichev L. F., Fedoseev P. N., et al. (eds.). Filosofskij ènciklopedičeskij slovar' [Philosophical Encyclopedic Dictionary]. Moscow: Sovetskaâ ènciklopediâ, 1983, 840 p. (In Russian).

10. Kostinskij G. D. Geografičeskaâ matrica prostranstvennosti [Geographic matrix of spatiality]. Izvestija RAN. Serija geograficheskaja [Bulletin of the Russian Academy of Sciences. Geographical series], 1997, Vol. 5, pp. 16-31. (In Russian).

11. Kotlyakov V. M., Komarova A. I. (eds.). Elsevier's Dictionary of Geography in English, Russian, French, Spanish and German. Amsterdam - Boston - Heidelberg - London - New York - Oxford - Paris - San Diego San Francisco - Singapore - Sydney - Tokyo: Elsevier, 2007, 1048 p.

12. Maruniak E. O. Prostorovì dilemi globalizaciì ta ïh konceptualìzaciâ [Spatial dilemmas of globalization and their conceptualization]. Ukraïns'kij geografičnij žurnal [Ukrainian Geographical Journal], 2012, Vol. 4, pp. 36-42. (In Ukrainian).

13. Nêmec' K. A., Nêmec' L. M. Prostorovij analìz u suspil'nìj geografiï : novì pìdhodi, metodi, modelì [Spatial analysis in human geography: new approaches, methods, models]. - Kharkiv: KhNU ìmenì V. N. Karazìna, 2013, 228 p. (In Ukrainian).

14. Nêmec' K. A., Nêmec' L. M. Teoriâ ì metodologiâ geografičnoï nauki: metodi prostorovogo analìzu [Theory and methodology of geography: spatial analysis methods]. Kharkiv: V. N. Karazìn Kharkiv National University, 2014, 172 p. (In Ukrainian).

15. Olïnik Â. B., Stepanenko A. V. Vstup do social'nö̈ geografiï [Introduction to social geography]. Kyiv: Znannâ, 2000, 204 p. (In Ukrainian).

16. Podol's'ka Ê. A. Fìlosofiâ [Philosophy]. Kyiv: İnkos, Centr navčal'noï lìteraturi, 2006, 704 p. (In Ukrainian).

17. Racine J.-B., Bailly A. S. Geography and geographical space: towards an epistemology of geography. In: Espace géographique. Espaces, modes d'emploi. Two decades of l'Espace géographique, an anthology. Special issue in English. 1993, pp. 125-134. [DOI : https://doi.org/10.3406/spgeo.1993.3196].

18. Šablij O. Suspil'na geografiâ. Kniga perša. Problemi teoriï, istoriï ta metodiki doslìdžennâ [Human geography. Book 1. Problems of theory, history and methodology of research]. Lviv: LNU ìm. Ìvana Franka, 2015, 814 p. (In Ukrainian).

19. Sharygin M. D., Chupina L. B. Podhody k izučeniû geografičeskogo prostranstva-vremeni i problemy, svâzannye s nim [Approaches to the study of geographical space-time and the problems associated with it]. Geograficheskij vestnik [Geographical Bulletin], 2013, Vol. 2 (25), pp. 4-8. (In Russian).

20. Smelser N. J., Baltes P. B. (eds.). International Encyclopedia of the Social \& Behavioral Sciences. Pergamon, 2001, $17500 \mathrm{p}$.

21. Smirnov A. M. Obŝegeografičeskie ponâtiâ [General geographical concepts]. Teoreticheskaja geografija. Voprosy geografii [Theoretical geography. Geography issues]. Moscow: Mysl', 1971, Vol. 88, pp. 29-65. (In Russian).

22. Topčiêv O. G. Osnovi suspil'noï geografiï [Fundamentals of human geography]. Odesa: Astroprint, 2009, 544 p. (In Ukrainian).

23. Topčiêv O. G. Suspil'no-geografičnì doslidžennâ: metodologîa, metodi, metodika [Human geographical researches: methodology and methods]. Odesa: Astroprint, 2005, 632 p. (In Ukrainian).

24. Warf B. (ed.). Encyclopedia of Human Geography. London-New Deli: SAGE Publications, 2006, 648 p.

25. Witherick M., Ross S., Small J. A Modern Dictionary of Geography. 4th Edition. London: Arnold, 2001, $293 \mathrm{p}$.

\section{Список використаних джерел:}

1. Алаев Э. Б. Социально-экономическая география: понятийно-терминологический словарь / Э. Б. Алаев. - М. : Мысль, 1983. - 350 с.

2. Конт-Спонвиль А. Философский словарь / пер. с фр. Е. В. Головиной. - Москва : ООО «Издательство «Этерна», 2012. - $752 \mathrm{c.}$

3. Definition of 'Geospace' // The Economic Times [Електронний ресурс]. - Режим доступу : https:// economictimes.indiatimes.com/definition/geospace. [20 December 2019]. $-719 \mathrm{c}$

4. Философский словарь / под ред. И. Т. Фролова. 7-е изд., перераб. и доп. - М : Республика, 2001.

5. Geographical space / Euston96. Online encyclopedia. URL: https://www.euston96.com/en/geographical-space/ [20 December 2019].

6. Основи філософських знань. Філософія, логіка, етика, естетика, релігієзнавство : Підручник / М. I. Горлач, В. Г. Кремень, С. М. Ніколаєнко, М. П. Требін та ін. - К. : Центр учбової літератури, 2008. - 1028 с. 
7. The Dictionary of Human Geography / Edited by Derek Gregory, Ron Johnston, Geraldine Pratt, Michael J. Watts, and Sarah Whatmore. 5th Edition. - Chichester : Wiley Blackwell, 2009. - 1071 p.

8. Новейший философский словарь : 3 -е изд., исправл / сост. и гл. научн. ред. А. А. Грицанов. - Минск : Книжный Дом. 2003. -1280 с.

9. Философский энциклопедический словарь / Гл. ред. : Л. Ф. Ильичев, П. Н. Федосеев и др. - М. : Сов. Энциклопедия, 1983. - 840 с.

10. Костинский Г. Д. Географическая матрица пространственности / Г. Д. Костинский // Известия РАН. Серия географическая. - 1997. - № 5. - С. 16-31.

11. Elsevier's Dictionary of Geography in English, Russian, French, Spanish and German / compiled by V.M. Kotlyakov and A.I. Komarova. - Amsterdam - Boston - Heidelberg - London - New York - Oxford - Paris San Diego - San Francisco - Singapore - Sydney - Tokyo : Elsevier, 2007. - 1048 p.

12. Маруняк Є. О. Просторові дилеми глобалізації та їх концептуалізація / Є. О. Маруняк // Український географічний журнал. - 2012. - № 4. - С. 36-42.

13. Нємець К. А. Просторовий аналіз у суспільній географії : нові підходи, методи, моделі. Монографія / К. А. Нємець, Л. М. Нємець. - Харків : ХНУ імені В. Н. Каразіна, 2013. - 228 с.

14. Нємець К. А. Теорія і методологія географічної науки : методи просторового аналізу / Навчальнометодичний посібник // К. А. Нємець, Л. М. Нємець. - Х. : ХНУ імені В. Н. Каразіна, 2014. - 172 с.

15. Олійник Я. Б. Вступ до соціальної географії : навч. посіб. / Я. Б. Олійник, А. В. Степаненко. - К. : Знання, 2000. - 204 с.

16. Подольська Є. А. Філософія. Підручник / Є. А. Подольська. - К. : Фірма «Інкос», Центр навчальної літератури, 2006. - 704 с.

17. Racine J.-B. Geography and geographical space : towards an epistemology of geography / J.-B. Racine, A. S. Bailly // Espace géographique. Espaces, modes d'emploi. Two decades of l'Espace géographique, an anthology. Special issue in English. - 1993. - pp. 125-134.

18. Шаблій О. Суспільна географія : у 2 кн. Книга перша. Проблеми теорії, історії та методики дослідження : [Вибрані праці] / О. Шаблій. - Львів : ЛНУ ім. Івана Франка, 2015. - 814 с.

19. Шарыгин М. Д. Подходы к изучению географического пространства-времени и проблемы, связанные с ним / М. Д. Шарыгин, Л. Б. Чупина // Географический вестник. - 2013. - № 2 (25). - С. 4-8.

20. International Encyclopedia of the Social \& Behavioral Sciences / Smelser N. J., Baltes P. B. (eds.). - Pergamon, 2001. $-17500 \mathrm{p}$.

21. Смирнов А. М. Общегеографические понятия / А. М. Смирнов // Теоретическая география. Вопросы географии. - М. : Мысль, 1971. - № 88.- С. 29-65.

22. Топчієв О. Г. Основи суспільної географії : підручник для студ. географ. спеціальностей вищих навчальних закладів / О. Г. Топчієв. - Одеса : Астропринт, 2009. - 544 с.

23. Топчієв О. Г. Суспільно-географічні дослідження : методологія, методи, методика : навч. посібник / О. Г. Топчієв. - Одеса : Астропринт, 2005. - 632 с.

24. Encyclopedia of Human Geography / Edited by B. Warf. - London-New Deli: SAGE Publications, 2006. $-648 \mathrm{p}$.

25. A Modern Dictionary of Geography / by Michael Witherick, Simon Ross, John Small. 4th Edition. - London : Arnold, 2001. - 293 p. 